University of California

Agriculture and Natural Resources
ANR Publication 8535 | October 2015 UC

www.anrcatalog.ucanr.edu PEVIEWED

\section{Ansel Adams Spreads} Images of the Sierra in Popular Consciousness

Ansel Adams (1902-1984) was an American photographer and environmentalist whose iconic black-and-white photos of Yosemite National Park have become synonymous with wilderness and the national park system itself. His "Monolith, the Face of Half Dome" is considered his professional breakthrough, eventually leading to shows in large galleries and museums across the United States. Adams joined other photographers in using their art to promote social and political change, including the conservation of wilderness areas and limitations to development within natural areas. He spent part of every year in Yosemite photographing and leading month-long hiking and camping trips. He became a Sierra Club member and was elected to its board of directors. Adams was involved in many different environmental causes affecting the Sierra Nevada, the California coast, and Alaska to name a few (Tunage 2015).

\title{
California Naturalist Series Natural History of the Sierra Nevada
}

Introduction

T

The Sierra Nevada, the "Range of Light," is a treasured feature of the vast California landscape, and yet we can truly appreciate it only in bits and pieces due to its expanse, remote locations, and steep terrain. Whether you hike along the Pacific Crest Trail, fish from a trout stream, ski down the steep eastern slopes, or picnic beneath the spreading canopy of a valley oak in the foothills, there is no way to separate what it means to be a Californian from our beloved Sierra Nevada.

The goal of this publication is to provide an overview of some of the specifics about the Sierra Nevada, including its geology, climate, water resources, flora and fauna, human history, ecosystem services, and natural resource management issues associated

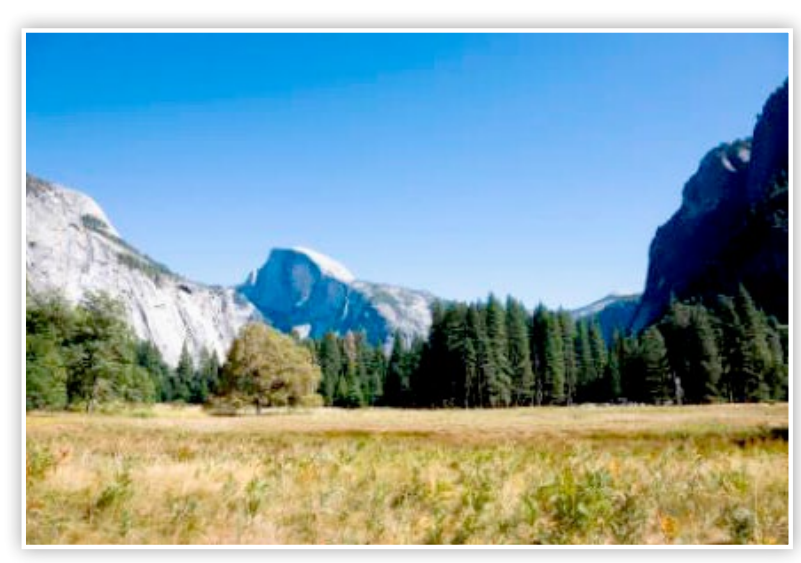
with human development. For those interested in natural history and environmental stewardship, this publication can provide an increased understanding of the Sierra Nevada's natural communities and the conservation challenges that a long history of land use, fire suppression, and resource extraction presents.

Half Dome, Yosemite Valley. Photo: ANR.

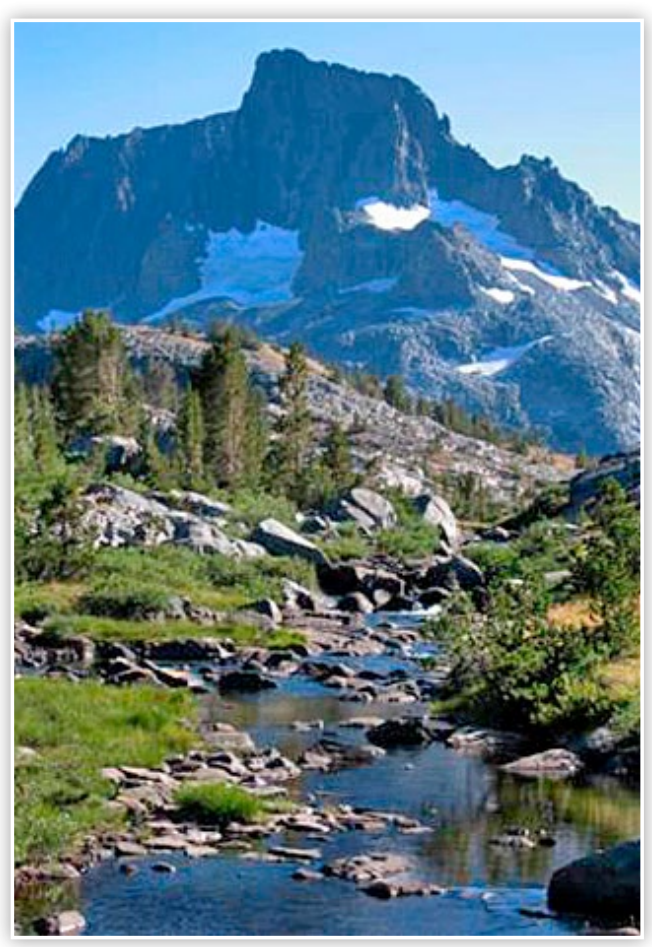

Banner Peak, Ansel Adams Wilderness Area. Photo: ANR.

KIM INGRAM, University of California Cooperative Extension Natural Resources Community Education Specialist, Davis, CA; SUSIE KOCHER, University of California Cooperative Extension Forestry and Natural Resources Advisor, Central Sierra Cooperative Extension, South Lake Tahoe, CA 


\section{John Muir Founds \\ Preservation \\ Movement in \\ Sierra Nevada}

John Muir (1838-1914) was one of the most influential people to recognize the majesty and significance of the Sierra Nevada. This Scottishborn American naturalist was one of the early voices for forest conservation and environmental activism. He traveled extensively throughout the Sierra Nevada, coining the phrase "Range of light" to describe its beauty. Through his prolific writing (over 300 articles and 10 books), he shared his experiences living in the Sierra, documenting its changes over the seasons, the impacts of grazing on meadows, and his theory of glaciation in Yosemite Valley. This "Father of the National Park System" assisted in the establishment of Sequoia and Yosemite National Parks, and his ideas helped President Theodore Roosevelt form the basis of many of his conservation programs. Muir was the founder and first president of the Sierra Club, which was used to carry forward the messages of environmental preservation and conservation (Sierra Club 2015).
The Sierra Nevada, sometimes referred to as the Sierra bioregion (fig. 1), is a vast area extending some 380 miles along the eastern side of California that includes rugged mountains, rolling oak woodlands and a myriad of riparian habitats. The area spans 18 counties, from the Pit River in northern Shasta County southward to Tejon Pass in the Tehachapi Mountains southeast of Bakersfield. This bioregion of approximately 31,000 square miles has an extremely diverse topography that ranges in elevation from 490 to over 14,400 feet. This area also contains the headwaters of twenty-four river basins and supports six different major vegetation zones. Over 60 percent of the bioregion is managed by either the U.S. Forest Service, the Bureau of Land Management, or the National Park Service (Kocher 2012). The Sierra has a rich and complicated history of human influence from Native Americans, gold miners, ranchers, and loggers, to vintners, farmers, and recreationists. The results of this influence can be seen through our towns, railroads, dams, and recreation facilities and how we deal with water management, wildfires, and climate change issues. The Sierra Nevada as a whole is a complex, diverse and interconnected environment whose resources benefit all Californians as well as people who live elsewhere.

The Sierra Nevada bioregion has many unique natural and human features. It contains the world's largest trees by volume, the giant sequoia (Sequoaidendron giganteum), which grows up to 279 feet tall and 26 feet wide; the highest peak in the contiguous US, Mount Whitney, at 14,505 feet; the largest and deepest alpine lake in the world, Lake Tahoe, with a surface area of about 200 square miles and depth of 1,640 feet; and the highest waterfall in North America, Yosemite Falls, with a 2,425-foot cascade. In addition to the natural wonders of the region, human influence has also played a significant role. Gold was found in the American River in January 1848, which had a huge impact on the Sierra Nevada as well as on California's population. Charles Crocker and others were instrumental in bringing the transcontinental railroad through the Sierra Nevada in 1868 . Over 100 reservoirs in the region

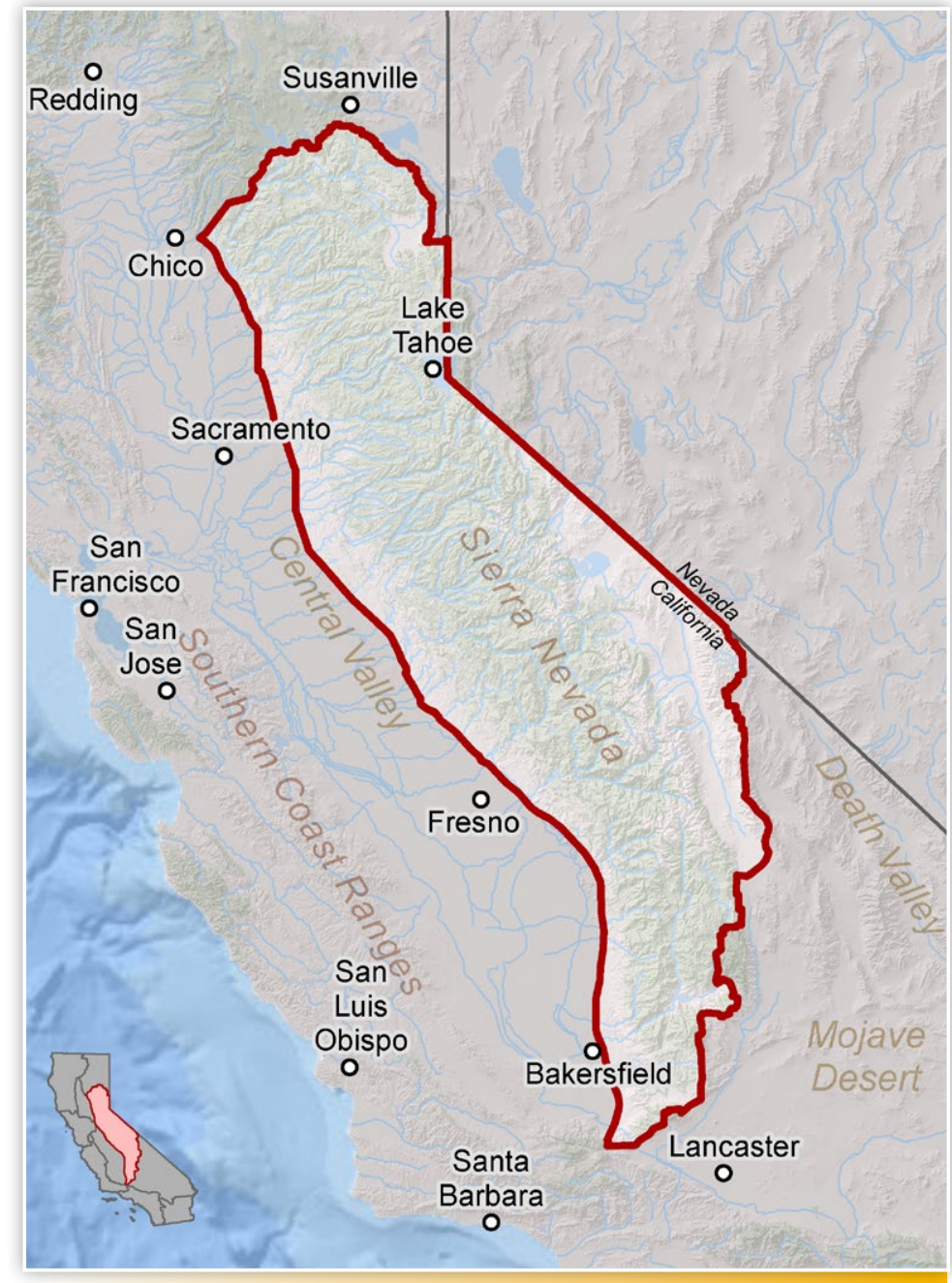

Figure 1. Sierra Bioregion.

are connected to more than 75 power houses that generate in excess of 4,000 megawatts of renewable electricity for nearly four million households (PG\&E 2015), and in 1961 construction began on the Oroville Dam on the Feather River, making it the primary supplier to the California State Water Project. 


\section{Geology and Climate}

An uplift of the earth's crust along a major fault line on the Sierra Nevada's eastern edge formed this westward-tilted mountain range, which extends more than 250 miles in length and is 50 to 80 miles wide. If you were to hike its east and west sides, you would find different geographic features that in turn shape its plant and animal communities. The abrupt uplift caused the eastern side to have sheer escarpments and steep gradient canyons, while the western side is characterized by more gradual foothills and alluvial fans. These alluvial fans were created out of valleys formed by the many glaciers that capped the Sierra Nevada range 14,000 to 80,000 years ago during the Pleistocene Age (James et al. 2002). You can still observe glacial remnants that include cirques, circular basins with steep walls; moraines, rock and debris that accumulated at the edges of the glaciers; and glacial lakes. The northwest-to-southeast orientation of the Sierra and orographic lifting causes the west side to capture more rain and snow from clouds originating over the Pacific Ocean. River channels oriented mostly east to west drain water toward California's Central Valley. The east side receives less moisture as a result of a rain shadow effect on the eastern side as the landform transitions into the Great Basin.

\section{Living in the Wildland-Urban Interface}

About 6 percent of the Sierra Nevada is classified as wildland-urban interface (WUI). In these areas, the fire threat to homes and communities is high because residential developments intermingle with wildland areas subjected to decades of fire suppression that now support dense vegetation with excessive fuel accumulation. The majority of U.S. Forest Service fire suppression costs occur within WUI areas. Many WUI communities were created before wildfire was a concern and lack important fire-prevention provisions. Because of this interaction between humans and wildland areas, maintenance of WUI areas takes collaboration between the community and government agencies

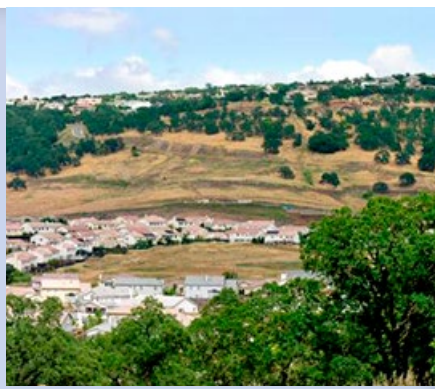

Urban encroachment into oak woodlands. Photo: ANR. to provide the best plan of action for management and planning in case of an emergency. In many Sierra Nevada communities, Fire Safe Councils have formed to help residents and businesses prepare their properties and create community wildfire protection plans to proactively prepare for wildfires. The goal is for residents to create fire adapted communities (see Fire Adapted Communities 2015).
There are more soil types in an individual Sierra Nevada county (93 in Nevada County alone) than in most other states. These soil types (entisol, inceptisol, alfisol, andisol, aridisol, mollisol, ultisol) (Van Wagtendonk 2006) are primarily based on a granite substructure, with some metamorphic and sedimentary parent materials. Factors such as climate, topography, and biological activity also cause variations in soil color, depth, texture, nutrient load, waterholding capacity, and soil formation rates. The most productive soils in the Sierra are found on the west slope mid-elevation ranges, where they support productive forests, ranches, orchards, and vineyards. At higher elevations and on the eastern slopes, soils tend to be shallower, less developed, and more coarsely textured.

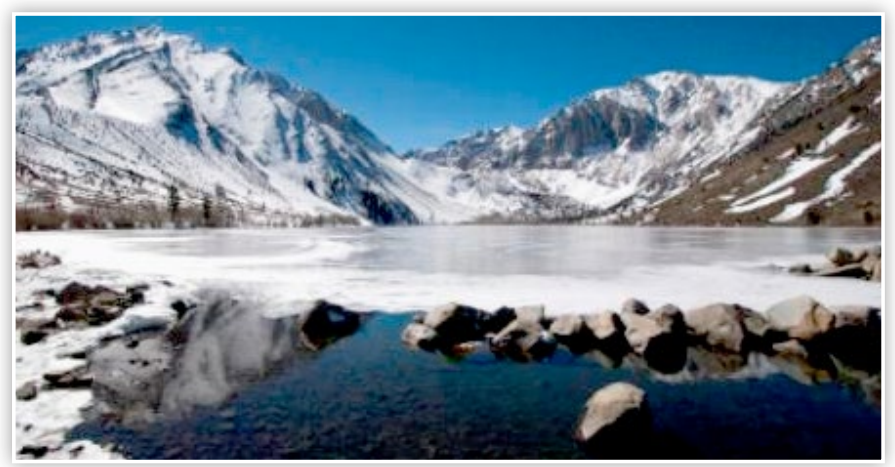

Convict Lake. Photo: ANR.

The climate of the Sierra Nevada is considered Mediterranean, characterized by cold, wet winters (November through April) and hot, dry summers (May through October). The rain-snow transition line during the winter months is approximately 5,000 feet in elevation at the northern end of the range and higher at the southern end, though this may be changing with climate warming. The Sierra receives on average 30 to 80 inches of precipitation, some of which may arrive as snow depending on elevation. The highest elevations can receive up to 38 feet of snow per year. Over 60 percent of California's developed water supply originates from this rain and snow, including approximately 50 percent of the flow into the Sacramento-San Joaquin Delta. 


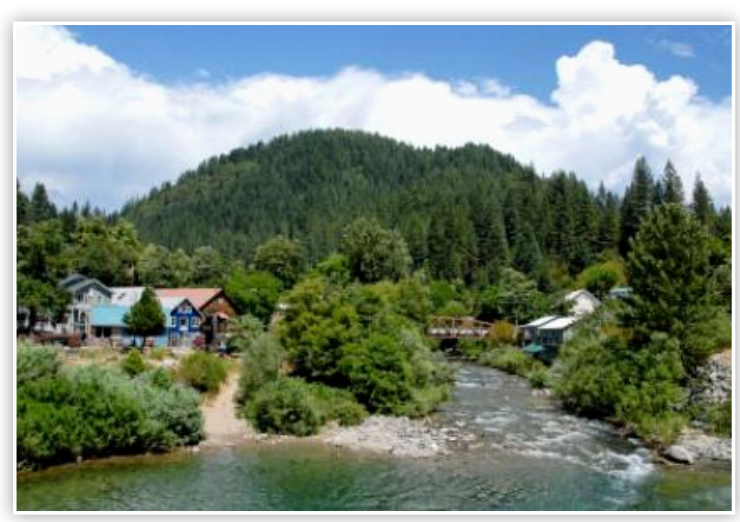

Yuba River at Downieville. Photo: ANR.

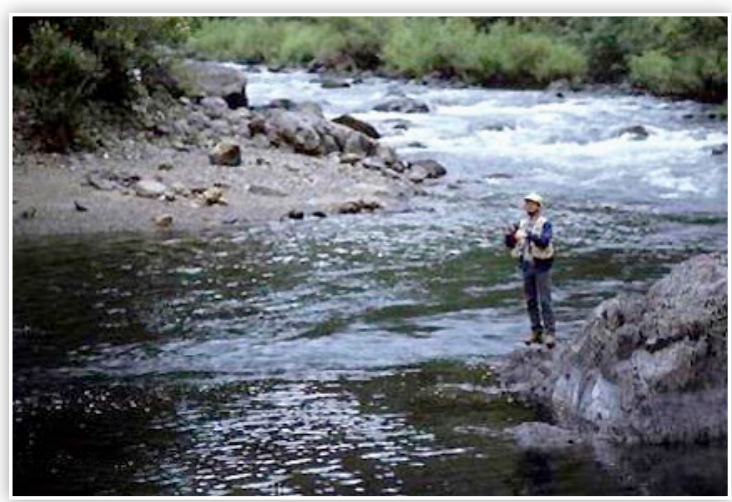

Fishing on the Merced River. Photo: ANR.

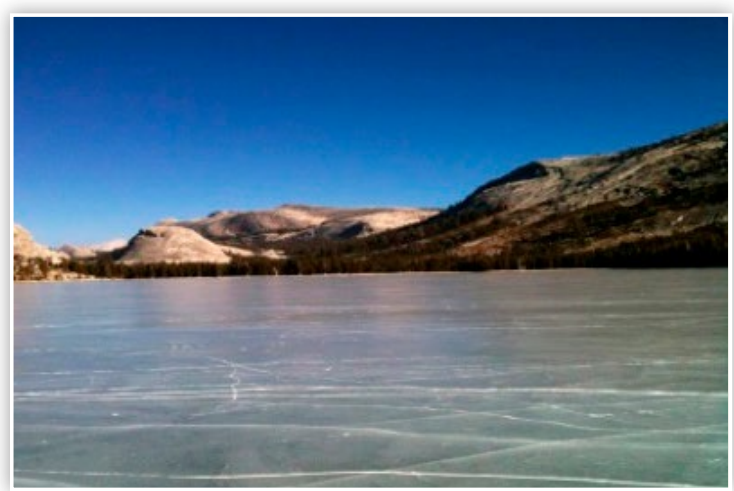

Frozen Lake Tenaya. Photo: R. Miller-Cripps.

\section{Watersheds}

Water issues, both supply and demand, are some of the most critical issues that face Californians today. The Sierra Nevada is the primary source of water for much of central and southern California, supporting both agriculture and municipal uses. The outcomes of natural processes such as drought or flood and water policy decisions such as water diversions affect millions of people and the state economy.

A watershed includes all of the land from which water drains through a common point. Watersheds are usually separated from one another by hills, ridges, or mountains. A watershed can be as small as a drainage into a pond or as large as the Sacramento River Basin. In the Sierra Nevada, there are twentyfour major watersheds (fig. 2) that drain to either the west or east sides. These include the Upper Sacramento, Feather, Yuba, American, Cosumnes, Mokelumne, Calaveras, Stanislaus, Tuolumne, Merced, San Joaquin, Kings, Kaweah, Tule, Kern, and Caliente on the west side and Eagle Lake, Honey Lake, Truckee, Carson, Walker, Mono Basin, Owens, and Mojave on the east side. These watersheds also include numerous lakes, some formed by retreating glaciers and others by accumulating precipitation, and streams that can run year round or go dry during the summer months.

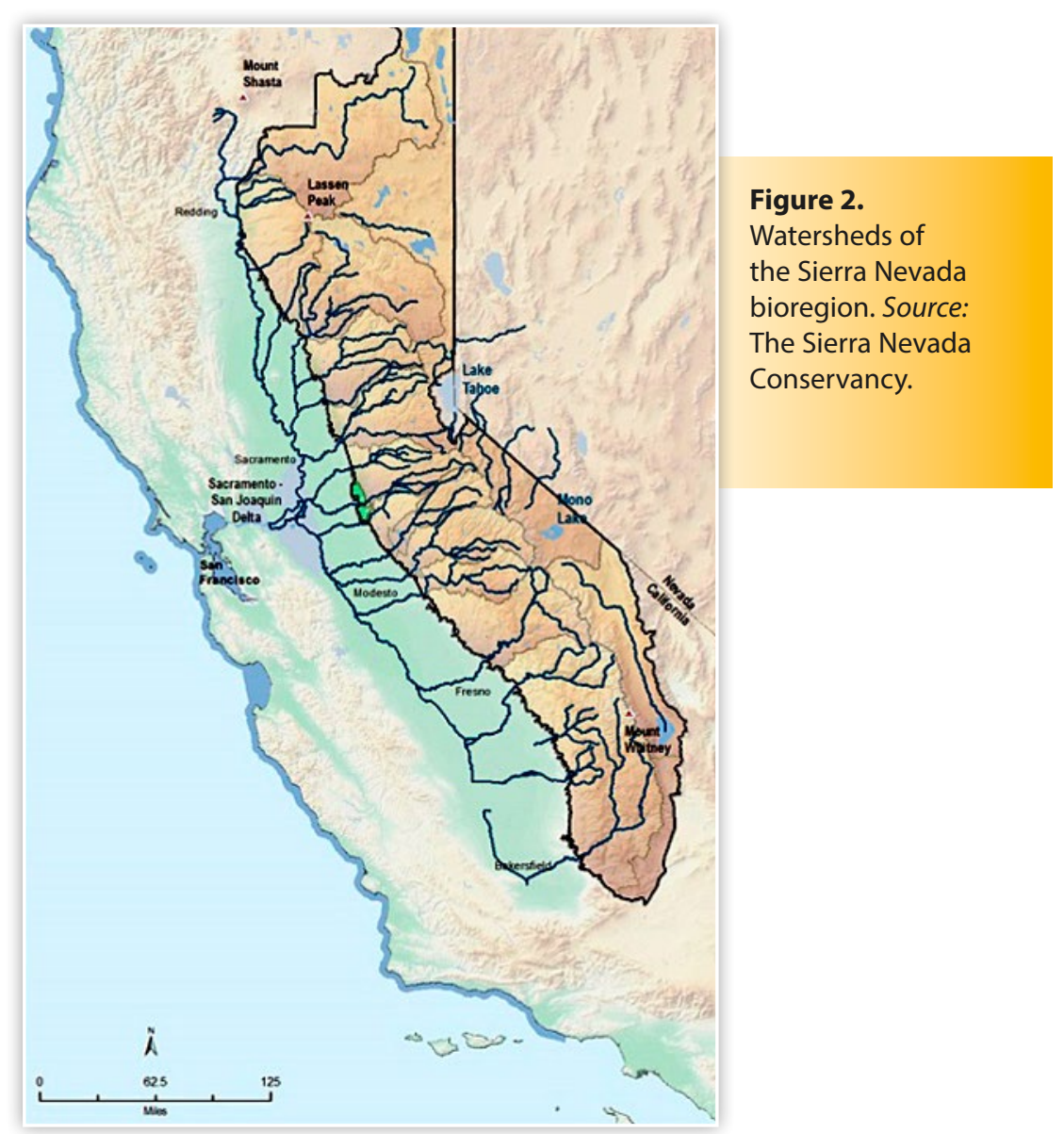

\section{Forest and Woodland Types}

The forest and woodland types found in the Sierra Nevada are classified by the dominant tree species found there, which is determined by environmental conditions and soil type. The most important environmental condition affecting species distribution is elevation. The growing environment gets colder and moister with shorter seasons as elevation (and latitude) increases.

In addition to soil preferences, differences among these species with respect to fire tolerance, water availability, and temperature greatly influences where these species grow. For example, mature 


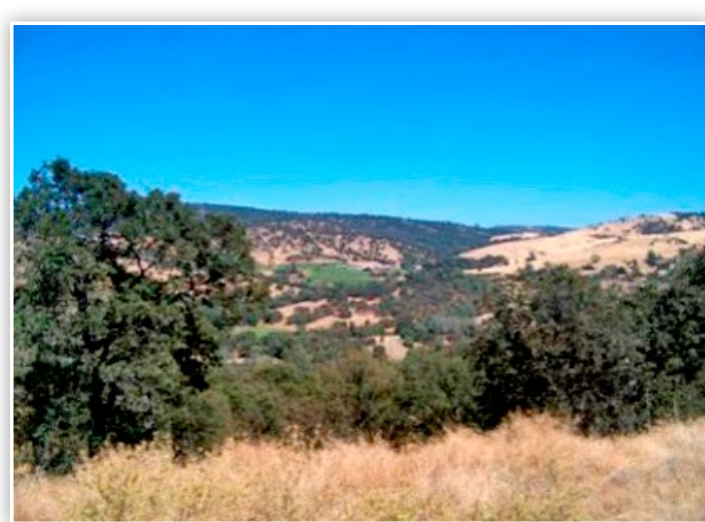

Oak woodlands at the University of California Sierra Foothill Research and Extension Center. Photo: ANR.

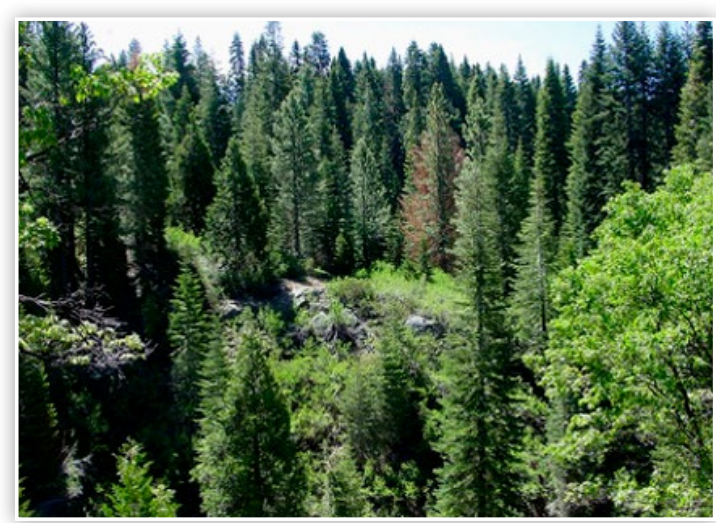

Mixed conifer zone on the Tahoe National Forest. Photo: S. Stephens. black oak and yellow pines are highly tolerant of fire and drought but intolerant of shade when compared with white fir, incense cedar, and Douglas-fir, which are less tolerant of fire and drought but grow relatively well in low-light conditions. With climate warming and dry seasons becoming longer, it is reasonable to expect that black oak and ponderosa pine will increase their range in the Sierra while subalpine forests will cover less area.

\section{Oak Woodland}

At lower elevations, scattered oaks dot the Sierra foothills as part of the oak woodland vegetation type. Valley oaks (Quercus lobate) and blue oaks (Quercus douglasii) with grass in between make up these woodlands that form such an iconic part of the California landscape.

\section{Montane Hardwood/Conifer}

Higher up from the valley floor, from 1,500 to 4,000 feet, depending on latitude, trees are intermixed with chaparral species, making up the montane hardwood-conifer type. Trees include hardwoods such as interior live oak (Quercus wislizinii), Oregon white oak (Quercus garryana), golden chinquapin (Chrysolepis chrysophylla) and canyon live oak (Quercus chrysolepis), along with conifers such as grey or foothill pine (Pinus sabiniana) and ponderosa pine (Pinus ponderosa). Tanoak (Notholithocarpus densiflorus) can be found in wetter areas such as between the Feather and American Rivers. California black oak (Quercus kelloggii) and canyon live oak are more common in drier sites; the latter is often observed on steep slopes with thinner soil. Pacific madrone (Arbutus menziesii) is found in scattered areas on the northern end of the range.

\section{Mixed Conifer}

As elevation and/or latitude increases, forests become dominated by conifers including ponderosa pine, sugar pine (Pinus lambertiana), white fir (Abies concolor), incense cedar (Calocedrus decurrens), Douglas-fir (Pseudotsuga menziesii), and black oak. Together these trees make up the Sierra Nevada mixed conifer forest type found between about 2,000 and 6,000 feet in the northern Sierra, 4,000 and 7,000 feet in the central Sierra, and 5,000 and 8,000 feet or more in the south. This zone also includes some chaparral stands dominated by ceanothus or manzanita, aspen groves, riparian forests, and meadows.

Within the mixed conifer zone are isolated pockets of giant sequoia (Sequoiadendron giganteum). These iconic trees occur naturally in 75 scattered groves along the western slope of the Sierra Nevada, mostly between the Kings River in Fresno County and the American River in Placer County. These giants are usually found growing in deep, well-drained soils with plenty of water. Not only can these trees grow very tall but they also can live a long time, reaching 800 to 1,500 years or older. Natural sequoia regeneration relies on disturbance such as fire to create canopy gaps where seedlings can get enough light and water to mature. Fire suppression in the Sierra Nevada has led to a lack of sequoia regeneration, although today fire is being used as a tool for restoration. Giant sequoia is also being planted more frequently on both public and private land for carbon sequestration purposes.

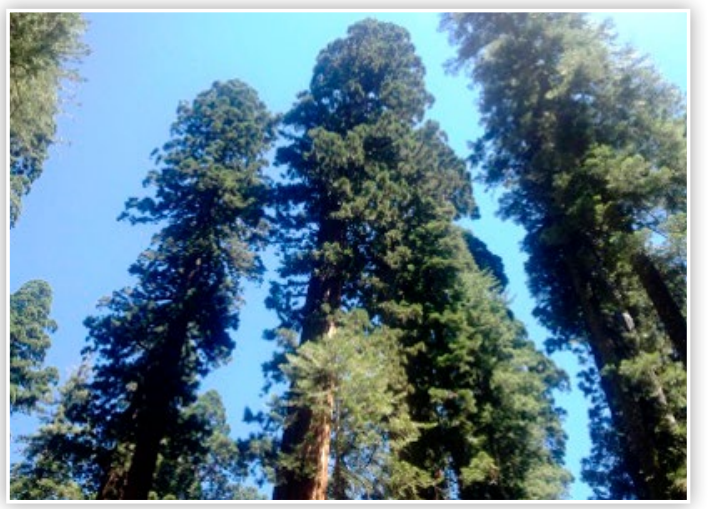

Giant Sequoias. Photo: S. Kocher. 


\section{True Fir Forest}

Above the mixed conifer zone are the true fir forests, dominated by white fir (Abies concolor) and red fir (Abies magnifica), western white pine (Pinus monticola) and lodgepole pine (Pinus contorta). These forests of the Sierra prefer cooler, wetter sites and are found at higher elevations and often on north-facing slopes. The forests can become dense and hence restrict understory light, which in turn limits shrub and herbaceous growth. This lower amount of understory vegetation, along with finer needles that are compacted by the snow load, reduces fire intensity and produces woody debris and snags that are valuable for cavity-dependent wildlife such as small mammals. Insect-gleaning birds, including yellow-rumped warblers, western tanagers, mountain chickadee, and goldencrowned kinglet, also inhabit the upper montane forests.

Jeffrey pine (Pinus jeffreyii) typically outcompetes ponderosa pine at higher elevations. Jeffrey pine is primarily found only in California, whereas ponderosa pine occurs throughout the western United States, southern Canada, and northern Mexico and can be found as far east as Kansas. The Sierra Nevada presents some of North America's harshest conditions, and the Jeffrey pine can tolerate colder, drier climates found at elevations from 5,600 to 9,200 feet in the northern and southern Sierra, respectively. Jeffrey pine is tolerant of serpentine soils and is often dominant in these conditions, even on dry sites at fairly low altitudes.

\section{Subalpine Forest}

Even higher up in elevation are subalpine forests, dominated by lodgepole pine (Pinus contorta), whitebark pine (Pinus albicaulis), and mountain hemlock (Tsuga mertensiana), often interspersed with meadow complexes. The gray and black feathered Clark's nutcracker is especially important to propagating the whitebark pine, which is in decline throughout its range due to infection by white pine blister rust (Cronartium ribicola), an invasive species that was introduced from Europe in about 1900 and made worse by outbreaks of mountain pine beetle (Dendroctonus ponderosae). The subalpine zone begins at 6,500 to 9,500 feet, depending on latitude and exposure, and extends upslope about 1,000 feet.

\section{Alpine Zone}

Just above treeline (above 7,500 feet in the north to 10,500 feet in the south) is the alpine zone, which is dominated by alpine meadow and shrubland with willow shrubs, grasses and sedges, and bare rock. This is considered the crest of the Sierra and a community visited by many hikers annually on their quest to summit Sierra peaks.

\section{Eastside Pine}

The eastside pine type is found on the east side of the crest where the forest becomes more open and drier, and is dominated by Jeffrey pine, single-leaf pinyon pine (Pinus monophylla), and western juniper (Juniperus occidentalis). Ponderosa and Jeffrey pines (sometimes jointly referred to as yellow pines) are closely related and occasionally hybridize with each other. Washoe pine, which has recently been reclassified as a ponderosa pine variety (Pinus ponderosa var. washoensis), occurs in three mountain ranges on the western rim of the Great Basin in northeastern California and northwestern Nevada. Washoe pine typically occurs in pure stands at higher elevations along the eastern slope of the Sierra. Below about 5,000 feet there is generally not enough precipitation to support trees, except within riparian areas and vegetation transitions to sagebrush and desert types.

\section{Biodiversity}

A biodiversity hot spot occurs where a particular ecosystem has lost a minimum of 70 percent of its original habitat and contains at least 1,500 species of endemic vascular plants. According to the California Academy of Sciences, the Sierra Nevada bioregion occurs within the California floristic province (CFP), which includes all areas west of the Sierra Nevada crest, southern California into northern Mexico, the many islands off of the California coast, and small areas of southwestern Oregon. The entire California floristic province has been identified as a biodiversity hotspot, with the Kern Plateau and southern Sierra Nevada being one of the most threatened (Conservation International 2005).

Within the Sierra Nevada, hundreds of endemic plant and animal species are found uniquely within the bioregion. In fact, out of an estimated 7,000 species of vascular plants known to 
occur in the Sierra Nevada, 400 are endemic. Many are also listed as rare and endangered. Information is limited on many of these species, as their occurrence is not evenly distributed throughout the Sierra or because they occupy hard-to-reach places. This huge variety of endemic species is a result of evolution and adaptation to the topography, climate, fire occurrence, geology, and soils that makes up the Sierra Nevada. Some species may be considered rare or endangered because of the range-wide suppression of frequent,

\section{Scientists Work to Reveal the Secrets of the Pacific Fisher}

Silently emerging after dark, the carnivorous Pacific fisher strikes out in search of a meal. Unbeknownst to it, University of California and U.S. Forest Service researchers have hung a tasty morsel to tempt it to a specific tree that contains monitoring equipment that will help scientists learn about these nocturnal mammals that roam the Sierra Nevada and Coast Range. The Pacific fisher, which once roamed throughout the length of the Sierra and the western parts of Washington, Oregon, and northern California, is being considered for listing as an endangered species in the southern Sierra due in part to low population numbers and habitat fragmentation. This member of the weasel family has a home range that averages over 30 square miles, lives in the canopy of dense mixed conifer forests from 2,500 to 6,500 feet in elevation, and is primarily a solitary animal.

They average 5 to 15 pounds in weight, have thick coats to help them stay warm in the winter, and have a sharp sense of smell to help them find food. Fisher kits will be moved by their mother several times during their first three months in order to help evade their primary predator, the bobcat. Adult males, which are
larger, are primarily preyed upon by mountain lions. Researchers have used tracking collars to learn more about their movement, preferred habitat, and, in the case of a collar that has stopped moving, their causes of mortality. One surprising finding is the extent to which these remote forest dwellers have been exposed to anticoagulant rodenticides, possibly due to the use of these toxic chemicals to protect illegal marijuana farms on public lands. Fourteen fishers were confirmed to have died of rodenticide exposure in California by 2014. Road kill is also a significant cause of death for fishers. In 2009, a reintroduction project was begun by the California Department of Fish and Wildlife, releasing 40 fishers into the northern Sierra Nevada and southern Cascade mountains on privately managed forest land. Researchers will monitor these fishers and their offspring for survival, reproduction, dispersal, and home range development for seven years with the hopes of reestablishing a viable population in the area (CDFG 2015). The multiple fisher studies being conducted throughout the Sierra are providing resource managers with information that will hopefully allow for better conservation of this species. low-intensity fire, which creates dense forests that preclude shadeintolerant shrubs and forbs.

\section{Animal Communities}

Approximately 400 species of terrestrial vertebrates can be found now or have existed in recent times across the Sierra Nevada, according to the California Wildlife Habitat Relationships System (CDFG 1994). Thirteen vertebrate species are endemic to the range, including the Yosemite toad (Anaxyrus canorus), Mount Lyell salamander (Hydromantes platycephalus), Limestone salamander (Hydromantes brunus), Kern salamander (Batrachoseps simatus), long-eared chipmunk (Neotamias quadrimaculatus), alpine chipmunk (Tamias alpinus), western heather vole (Phenacomys intermedius), Walker Pass or yellow-eared pocket mouse (Perognathus xanthonotus), and the golden trout (Oncorhynchus mykiss aguabonita). Some endemic species, including the grizzly bear (Ursus arctos), yellow haired porcupine (Erethizon epixanthum epixanthum), ringtails (Bassariscus astutus), fishers (Martes pennanti), pine martens (Martes americana), and wolverines (Gulo gulo), were once abundant, but their numbers have been reduced to isolated populations or are no longer found in the Sierras.

Historically, forests were patchier than they are today, providing a range of forest structures and habitat that included gaps, shrub patches, and open forest conditions. The historically high species richness of Sierra forests probably is due in part to this constantly shifting habitat and microclimate conditions. For example, a study of breeding birds observed over a 25 -year period found that community structure changed between species with different foraging strategies (i.e., from foliage searching to bark gleaning) as forest succession progressed (Raphael et al. 1987).

Some animals prefer conditions for each of these seral stages, including those that are most common in older, denser forests such as California spotted owls (Strix occidentalis), northern goshawk (Accipiter gentilis), fisher, pine marten, southern red-backed voles (Clethrionomys gapperi), and northern flying squirrels (Glaucomys sabrinus). An increasing focus on public lands is to maintain preferred habitat for these threatened species by retaining older, 
larger trees used for nesting and resting by species such as spotted owls and fishers. Maintaining snags burned by wildfire is important for the vertebrate species that use snags for habitat and food.

A recent statewide analysis of historical data found that from the 1930s to the 2000s, large tree numbers declined by half in the Sierra Nevada while small tree density doubled (McIntyre et al. 2015). Another recent study, of a site in the Central Sierra, found nine times as many dead standing trees and three times as many dead logs on the ground compared to conditions in 1929, though these were much smaller on average. Current dead wood dynamics do not necessarily favor cavity nesters, however, as smaller trees and snags are typically less suitable for primary cavity nesters such as woodpeckers and nuthatches that create and vacate cavities that are then used by other birds and mammals.

\section{Fish}

In the Sierra Nevada, there are 24 native fish species, 11 of which are endemic. These include the golden trout (Onocorhynchus aguabonita), rainbow/steelhead trout (Oncorhynchus mykiss), Lahontan cutthroat trout (Oncorhynchus clarki henshawi), and Chinook salmon (Oncorhynchus tshawytscha). Historically, almost none of the lakes and streams above 6,000 feet in the Sierra contained fish. Now, over 60 percent of those water

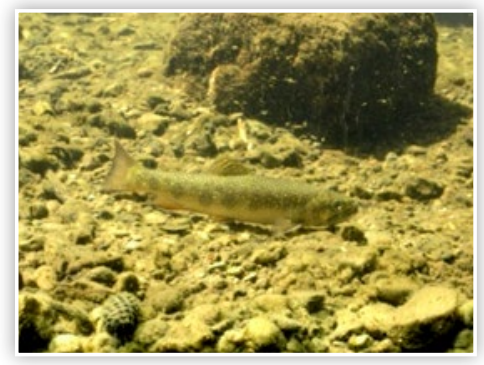

bodies contain non-native trout and bass species that were introduced to support the recreational fishing industry. The California Department of Fish and Wildlife operates several hatcheries in the Sierra Nevada that raise over 30 million brown trout, eastern brook trout, and salmon fry annually. Non-native fish have spread throughout the Sierra and have had unintended consequences such as hybridization and competition with native fish, introduction of lethal pathogens, and increased predation on amphibians. Along with habitat degradation and fragmentation, native fish

Lahontan cutthroat trout. Photo: K. Ingram. organizations exist to protect and restore wild trout and steelhead waters throughout the Sierra Nevada and California.

\section{Birds}

Because of the extraordinary amount of diverse habitat, the Sierra Nevada supports over 200 regularly occurring bird species. Some of these species are permanent occupants, while others may spend time in the Sierra breeding and rearing or as a stop along their migration routes. Some species

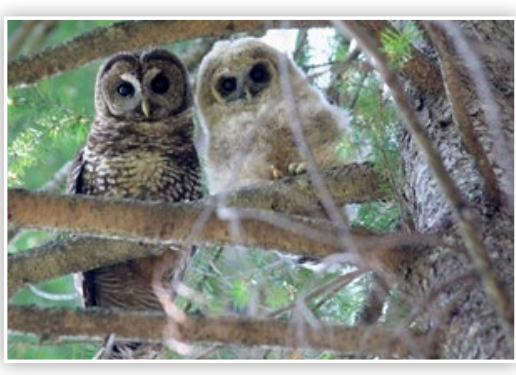

California spotted owl. Photo: S. Whitmore. can be found in many different ecosystems, while others are more selective. For example, in Sierra County, permanent or seasonally flooded areas create large freshwater marshes with a variety of rushes, sedges, reeds and cattails to provide excellent habitat for Canada geese (Branta canadensis), marsh wrens (Cistothorus palustris) and great blue herons (Ardea herodias) (Beedy 2013). Chaparral on lower elevation slopes are home to several sparrow species; montane meadows support declining populations of willow flycatchers (Empidonax traillii) and the great grey owl (Strix nebulosa); and old-growth mixed conifer forests are the preferred habitat of California spotted owls and northern goshawk. Some species, such as hummingbirds and jays, are better at adapting to areas with a human presence and are found throughout the Sierra.

Changes to bird habitat caused by fire suppression and subsequent high-severity fire as well as from human uses such as livestock grazing, timber harvest, and residential development change the distribution and stage of development of vegetation and can have localized negative effects on occupancy and reproduction of birds using a specific habitat. Some songbirds associated with shrub communities have become increasingly rare in fire-suppressed forests, where light is limiting. Climate change is altering the range where birds are found in the Sierra Nevada because of changes in temperature (cool weather birds moving upslope) or precipitation 


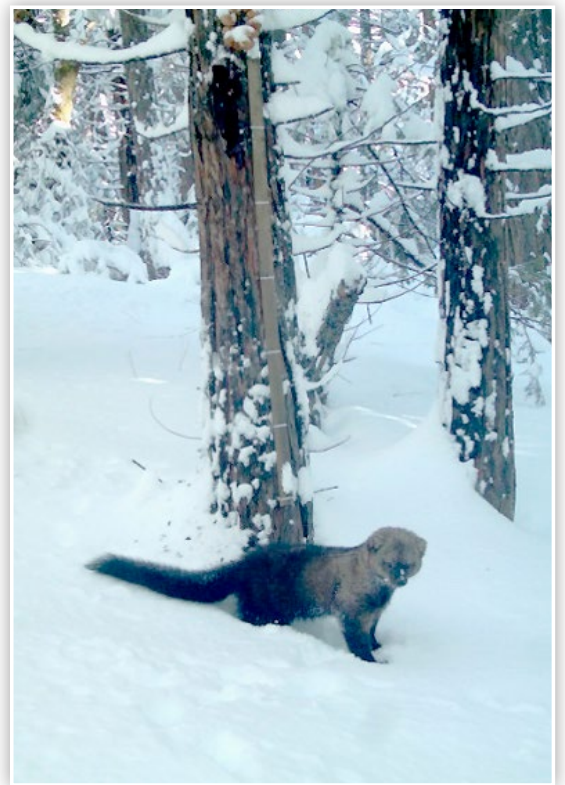

Pacific fisher. Photo: SNAMP remote camera. (excessive moisture in an area during breeding, which can force birds to move). Birds also have their champions in the Sierra Nevada, with their mission to conserve and restore natural ecosystems for birds and to promote conservation through public outreach programs such as observation through field trips, bird surveys, and environmental education programs.

\section{Mammals}

The Sierra Nevada is home to approximately 135 mammal species spread across its diverse habitat and topography, from the tiny pika (Ochotona prineps) that lives in the alpine mountain tops to the California mule deer that lives in the mixed conifer forests and oak woodlands, to bats that occur at almost every elevation. Rodents have the highest proportion of the total mammalian species in the Sierra. Since California grizzlies, which are depicted on the state flag, became extinct in 1924, the black bear has been the largest mammal in the Sierra, with males averaging from 300 to 350 pounds and females 150 to 200 pounds. In December 2011, scientists and the general public took note of the first known gray wolf to enter California since the early 1920s, identified because it was wearing

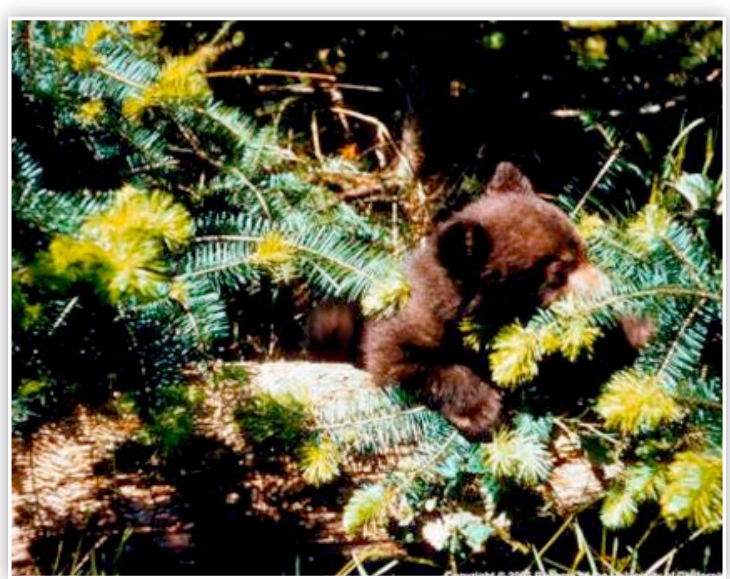

a tracking collar. Named OR-7, the gray wolf did not stay long, returning to southcentral Oregon where he found a mate and had offspring. The wolf represents a species which is currently recolonizing its historical habitat in the Sierra Nevada without a government-sponsored reintroduction program.

Insects

Over 30,000 insect species are known to reside in California, with more being discovered. One of the most pleasing things Black bear cub. Photo: ANR. to watch the many kinds of butterflies that can be found there. Some are endemic, including Behr's colias butterfly (Colias behrii), which is found only in a small area around Tioga Pass. The best place to find and observe butterflies and other insects, including ants, mites, beetles, leafhoppers, flies, spiders, wasps, bristletails, true bugs, grasshoppers, caddisflies, moths, and lacewings, is to spend time in lower and wetter sites.

\section{Sensitive Species}

Like Sierra Nevada fish and bird species, mammals are also facing potential threats due to habitat fragmentation and degradation caused by a number of factors, including residential and urban development, large and severe wildfires, vegetation management, pesticide use, and competition from invasive species and climate change. Some, like the Sierra Nevada bighorn sheep (Ovis canadensis sierrae), have experienced dramatic decline due to the introduction of viruses from domestic sheep. In general, depending on their degree of loss in population and/or habitat, wildlife can be classified into five protective categories or a combination thereof: federally endangered, federal candidate, state endangered, state threatened, or California species of concern. In Yosemite National Park alone 14 animal species (not including fish, insects, birds, or invertebrates) are listed in the five protective categories, due in part to historic over-trapping, reduction in suitable habitat, and competition from non-native species. The Sierra Nevada yellow-legged frog (Rana sierra), Sierra Nevada bighorn sheep, Sierra Nevada red fox (Vulpes vulpes necator), Pacific fisher, and wolverine are examples of species that have either been listed or are under consideration for listing (National Park Service 2015).

\section{Disturbance and Adaptation}

Evolutionary adaptations are changes in an organism's structure or habit that make it more suitable to live and reproduce in its environment. Adaptations can occur in response to physical conditions like climate, soil types, and water availability; to recurring ecosystem disturbances such as droughts, hurricanes, tornadoes, or cold spells; or to more complex relations with the environment, such as competition and predation. 
One of the primary disturbances causing adaptation in organisms in the Sierra Nevada is fire. Predating Euro-American settlement in the late 1800s and fire suppression activities that began in the early 1900s, fire regularly occurred on the Sierra landscape. Past fire frequencies have been estimated by researchers through analysis of fire scars in tree rings in live and dead trees (fig. 3). Looking at Sierra forests as a whole, almost half would have burned at low intensity at least every 12 years and 75 percent would have burned at least every 20 years, on average. This compares to less than 0.2 percent that currently burns in prescribed and wildfires, most of which occur in national parks. About 75 percent of the Sierra landscape has not had a wildfire or prescribed burn in over 100 years.

Frequent low-intensity fires can benefit the ecosystem by reducing competition for water and nutrients, increasing soil $\mathrm{pH}$, destroying allelopathic chemicals and pathogens, clearing the undergrowth to create forest openings that allow for seedling growth, clearing seedlings and small trees in meadow complexes, and stimulating plant regeneration and/or seed germination. Many plants in the Sierra have physical characteristics that help them survive fire, such as thick bark, deep taproots, high moisture content in their needles or leaves, and resins that aid in the healing burns. These species include greenleaf manzanita (Arctostaphylos patula), giant sequoia, and ponderosa pine. Many Sierra plants, such as oaks and ceanothus, have latent buds in their root crown that enable them to resprout after a fire.

Without frequent low-intensity fires, shrubs and small trees have proliferated, leading to a huge buildup in forest fuel, which has in turn led to an increase in the size and frequency of high-severity fires in which most or all trees are killed. Wildfires now routinely kill more large trees over larger areas than would have been the case before fire suppression. Centuries of natural fires and the reburning of partially revegetated sites would have probably created a much more varied landscape than the emerging pattern of unbroken dense forests that experience large areas of high severity fire that were supported by continuous high amounts of available fuel.

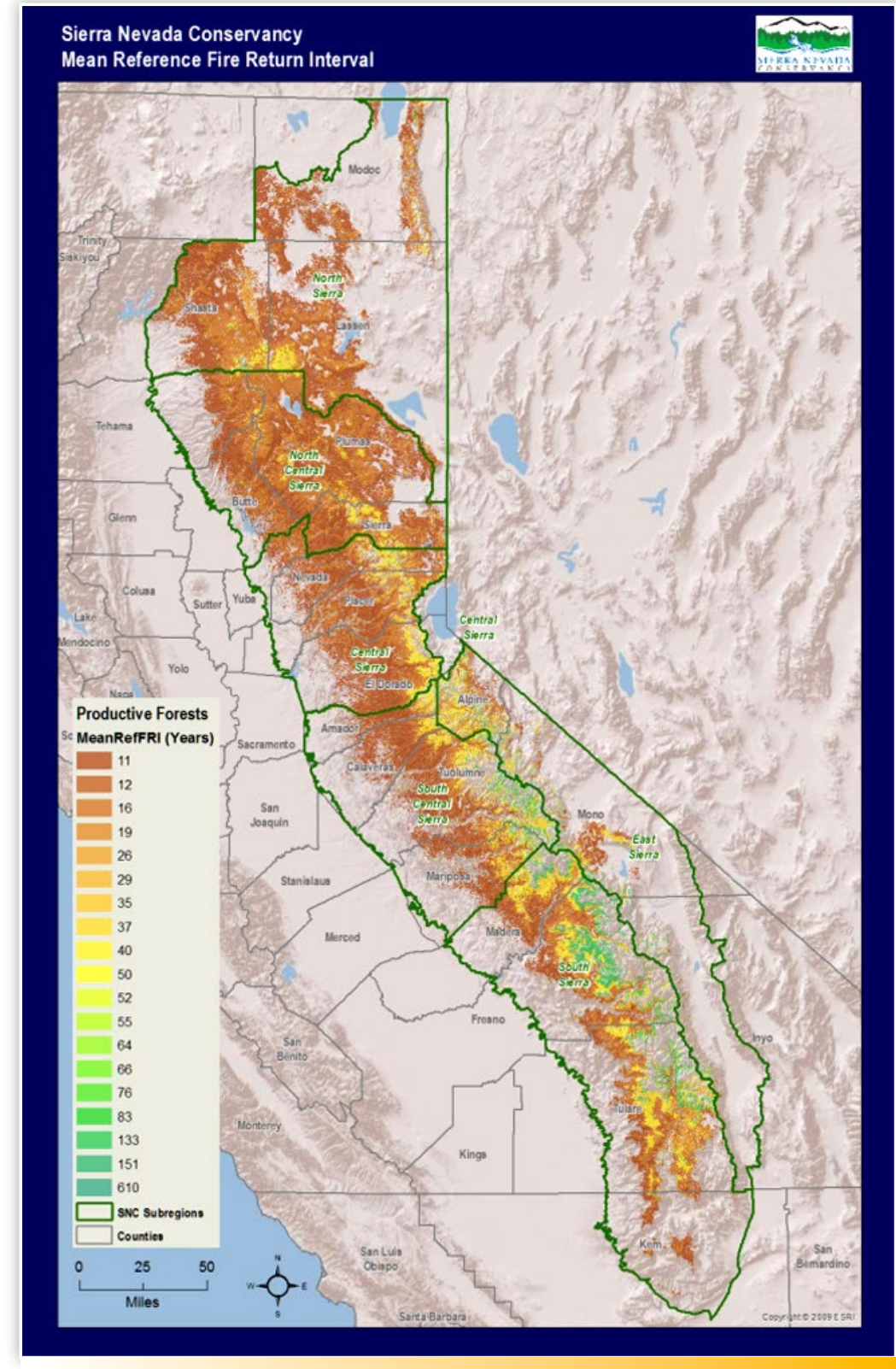

Figure 3. Mean reference fire return interval. Source: Map by Steve Beckwitt, Sierra Nevada Conservancy. 


\section{Hydraulic Mining Battle Begins}

\section{Era of Environmental Regulatio}

Hydraulic mining was a controversial though effective method of recovering almost 11 million ounces of gold in the Sierra Nevada. Under high pressure, water was shot through a nozzle or cannon at hillsides and gravel deposits. The debris, measuring in the tons, would then wash down into a series of enormous sluice boxes that miners used to sort out gold. In addition, mercury was used to process finer debris and capture gold flakes and dust. However, hydraulic mining had devastating effects on its surrounding environment as well as on communities and environments downstream. Some estimates claim between 40 to 60 million gallons of water were used each day. Almost 3 million cubic yards of debris (rocks, trees, and sediment) were created each year and deposited along and in the various rivers in the Sierra and the foothills (Kuchera and Hester 2009).

This debris buildup caused water quality issues (high sediment and mercury loads), alterations of stream and river channels, and flooding of downstream communities. In 1882, a suit was filed against all mines working on the Yuba River citing the negative effects on the river and those who lived along it. In 1883, a judge in San Francisco ruled against the mines and put a halt to all hydraulic mining in California. A federal court upheld the ruling in 1884 .

\section{Human History}

Humans have left their mark on the Sierra Nevada for thousands of years. Five main Native American tribes call this bioregion home and have used and managed its resources: the Yokut, Sierra Miwok, Maidu, Paiute, and Washoe, and their many smaller family groups. Through hunting, fishing, forest and meadow burning, harvesting, and irrigation practices, the Sierra Nevada forests and meadows provided the materials needed for food, clothing, shelter, and trade. In the early 1800 s, non-Indian settlers came into the Sierra Nevada and began their own agriculture, mining, logging, and grazing practices. Native tribes were decimated by this contact as a result of disease, forced relocation, appropriation of land, and murder.

Although thousands of Native Americans still live in the Sierra, only a few, small areas of land are Indian owned in the range. Some tribes are still working toward becoming Federally recognized, such as the Colfax-Todd's Valley Consolidated Tribe. This tribe is comprised of people who were born of Miwok and Maidu (Nisenan) ancestry who live in the Colfax and Foresthill area. They are currently working with local nonprofits to help maintain their culture and traditions and share them with neighboring communities. Other groups, such as the Maidu Cultural and Development Group in Greenville, have worked to secure management opportunities within the Plumas National Forest, which took over their lands so that they may practice management of important cultural plants such as beargrass and willow used in traditional basket making.

\section{Public and Private Land Ownership}

The Sierra Nevada is a checkerboard of landownership between public and private owners. In the 1860 s, as an incentive for the westward expansion, Congress authorized every other square mile of land to be made available for private ownership to railroad companies, with the alternating square miles to become national forest. This supported the finance and construction of the railroad through the Sierra by the sale and use of its natural resources. Since then, some of these private landholdings have been sold or converted from railroad ownership into other private hands. These parcels, along with other private land, account for the 29 percent of the productive forest land in the Sierra (Kocher 2012).

Private land ownership exists in many forms, such as private timber companies, land trusts, ranches, and individual residential parcels. Another landowner is the University of California Natural Reserve System, which has five reserve and field stations in the Sierra that provide access to academics and their students for longterm teaching and research opportunities. These reserves range in size from 154 acres in the high desert of the Sierra to over 9,000 acres at the northern edge of Yosemite National Park (UC 2015).

\section{Mining}

The discovery of gold on the American River in 1848 led to a huge influx of settlers, both to mine for gold and to support the miners, primarily through agriculture. By 1849 , gold was found as far south as the Tuolumne River and north to the Trinity River. Advancements in gold mining techniques from panning and sluicing to dredging, hydraulic mining, and underground hardrock mining by the $1870 \mathrm{~s}$ had profound effects on Sierra ecosystems. Mining and the activities that supported it included disturbance of stream channels, intensive logging of forests, conversion of land to agriculture and grazing, road building, stripping of hillside vegetation and minerals, water diversions, and declining water quality due to the presence of silt and mercury.

A limited number of commercial gold mining operations still occur today. Yuba Gold Dredge No. 17 is a floating dredge that digs up one side of a flooded gravel field area near Yuba City and deposits the sand, cobble, and gravel on the other side of the field as it collects gold dust. Individuals can try their hand at gold panning along many rivers and streams in the Sierra, including specific areas 


\section{Hetch Hetchy Fuels Controversy}

\section{over Dams and Water Supply}

During the 1880 s, the city of San Francisco sought to secure a reliable fresh water source for its growing population.

City officials looked toward the Hetch Hetchy Valley, located in the northwest part of Yosemite National Park, and the construction of a dam on the Tuolumne River, as a possible solution. Intense debate over this idea pitted well-known advocates such as Sierra Club founder John Muir, who wanted to keep the valley undammed, against Gifford Pinchot, leader of the U.S Forest Service, who advocated multiple uses of national forests. After many years of debate and an act of Congress, San Francisco was granted the right to develop a water conveyance and power generating system in Hetch Hetchy Valley. In 1923, the O'Shaughnessy dam was completed, and a year later the Moccasin Creek Power Plant began generating power. By 1934, the entire project was complete and O'Shaughnessy dam was providing 25 percent of the fresh water needed for San Francisco and other South Bay communities.

The completion of the project, however did not end opposition. In 2000, the "Restore Hetch Hetchy" movement became a more organized and recognized group calling for removing O'Shaughnessy Dam and supporting measures of water diversions, increasing storage capacity on other down-river facilities, replenishing ground water basins, and using a mixture of water conservation and recycling activities to replace the water that would be taken out of storage if O'Shaughnessy Dam were removed. of the Marshall Gold Discovery Park in Coloma. Be advised, though, that many areas along Sierra streams and rivers are privately owned or subject to legal mining claims requiring landowner permission before you search for your fortune. Small-scale suction gold dredging has been subject to a moratorium since 2009.

\section{Transportation}

In 1865, work began on the western portion of the transcontinental railroad. Beginning in Sacramento, the railroad had to cross the Sierra before dropping into Nevada and continuing east. This effort included up to 12,000 men using explosives to tunnel through granite, building bridges across steep ravines, and surviving harsh winter weather. By summer 1867, the workers had completed this monumental task and were on their way into Nevada. Trails, roads, and automobile connections opened much of the Sierra to travelers by the end of the 1930s.

\section{Timber Harvest}

Timber harvest in the Sierra Nevada before 1900 was done primarily in service of mining activity, camps, and towns. It also supported home-building in the Central Valley and railroad construction in the state. Logs and lumber were sometimes moved through water-filled flumes up to 60 miles long, which also required a great deal of wood to construct. Regulation of logging on public lands began with the creation of national forests and the United States Forest Service, which is charged with their management. Moreremote areas started to be harvested by the 1920s, with the development of railroad logging systems. Chainsaws, trucks, and tractors were in use for harvesting by the mid-1940s. Much of the federal forest land was not harvested until after World War II. Federal harvests climbed rapidly after that in an effort to build homes for returning GIs and peaked at about 800 million board feet in the late 1980s. Private harvests peaked in 1952. The ZebergNejedly Forest Practices Act of 1973 brought reforms that required greater attention to protecting nontimber attributes of forests such as water quality and wildlife habitats. The timber industry contracted in the later part of the twentieth century, and many mills were closed, largely due to reduced timber harvest from national forests.

\section{Grazing}

Most of the Sierra Nevada has been grazed at some point in time. Cattle were driven up into the mountains first to supply Gold Rush markets where Sierra meadows were used as summer range for livestock that were quartered at lower elevations the rest of the year in a cycle known as transhumance. Millions of sheep also grazed throughout the range at that time, making a profound effect on herbaceous species. Demand for higher-elevation grazing, much of it on now-federal land, was also high during the world wars and Great Depression. Grazing decreased by the end of the twentieth century due in part to changes in federal land management policies. There is also much less fodder available now since fire suppression has allowed grass and shrubs to be crowded out by trees. Private lands in the Sierra still support grazing, and visitors might also spot llama and alpaca herds along with the cattle, sheep, and goats.

\section{Water Development}

By 1900, water was being tapped to send to California cities, and hydroelectric dams and generation facilities were being built. The federal Bureau of Reclamation increased water development in the Sierra during the Great Depression, beginning construction of the series of dams and canals in place today. The completion in 1978 of the New Melones Dam on the Stanislaus River marked the completion of this phase in large-scale water projects.

\section{Recreational Development}

Early immigrants, just like today's visitors, were struck by the beauty of the Sierra. These early visitors came by horseback and 
Lake Tahoe Region Becomes Entry to the Sierra for Millions Annually

The history of Lake Tahoe begins over two million years ago, with the uplifting of fault blocks that formed the Sierra Nevada and Carson ranges and the sinking of the plains between them. Next, lava flows dammed the Truckee River, which ran through the plains. Glaciation effects and the collection of rain and snow filled the depression, and Lake Tahoe was formed. The watershed of Lake Tahoe covers about 312 square miles, and over 50 streams and rivers flow into it. Its only outlet is the Truckee River, which flows northeasterly into Nevada's Pyramid Lake. The amount of water in the lake is estimated at about 39 trillion gallons.

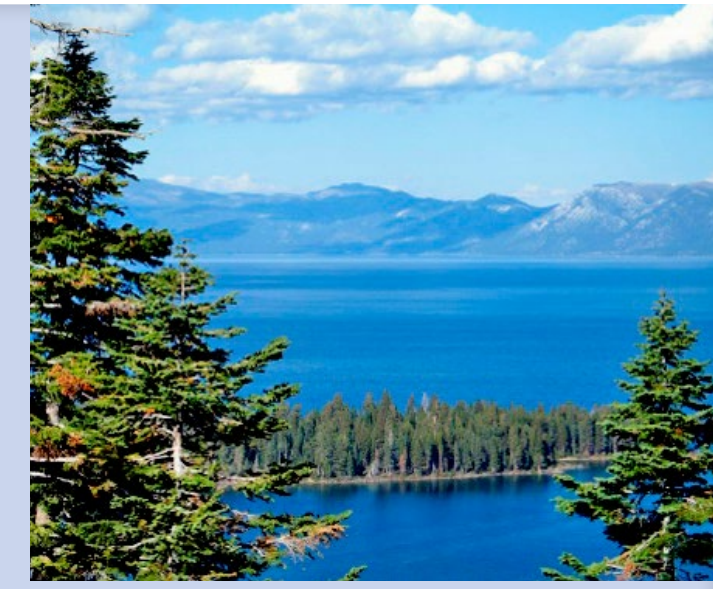

Emerald Bay, Lake Tahoe. Photo: Christine B.
The Lake Tahoe region, surrounded by forests of Jeffrey pine, cedar, and fir, is considered sacred by the Washoe Tribe, who settled in the area thousands of years ago. In 1844, a scouting party including General Fremont and Kit Carson came across Lake Tahoe for the first time and established the area as the place to cross the Sierra Nevada into California. The area remained lightly populated until the discovery of silver in the 1860s in nearby Virginia City. With that discovery, thousands of miners, loggers, and others settled in the Lake Tahoe basin to support the silver mining industry, forever changing the natural environment.

Today, the Lake Tahoe region supports year-round recreation, including casinos and resorts, fishing, biking, hiking, sailing, hunting, and winter sports. In 1960, Squaw Valley (between Truckee and Tahoe City) hosted the Winter Olympics, cementing Lake Tahoe's reputation as a premier winter sports destination. Today, the region has a permanent population of about 65,000 people and hosts over three million visitors annually.

Both naturally occurring events and the effects of human interaction have led to changes in the lake. According to the Tahoe Environmental Research Center's State of the Lake Report 2014, climate change and local pollution have altered the chemistry and aesthetics of the lake. The center has been continuously monitoring the lake since 1968 and over that time has recorded fluctuations in the lake's characteristics, including a general trend toward lower water level, higher temperature, lower clarity and an increase in invasive species. The downward trend in clarity has been stabilized and partially reversed in the last few years. This is due in part to the large investments by the federal, state, and local governments to reduce pollution in urban and residential runoff. Projects have included pumping of all treated wastewater out of the Lake Tahoe basin, storm water detention basins, removal of septic tanks, meadow and marsh restoration, stream stabilization, and forest thinning to diminish the potential for high-severity wildfire (Tahoe Environmental Research Center 2014). stagecoach. Railroad development allowed for an increase in tourism to Yosemite and other scenic areas. Recreational guides for tourists were abundant by the 1900s. By the 1920s, auto traffic increased the recreational use of national parks, and the Tahoe area and allowed tourism in areas throughout the Sierra along the improving road systems. In 1924, the first ski resort in Tahoe, Granlibakken, opened near Tahoe City, and it is still in business today. After World War II, many more ski resorts of various sizes and amenities opened. A high point was the Squaw Valley Ski Resort hosting of the 1960 Winter Olympics.

\section{Residential Development}

Euro-American settlements began in the 1800s with boom-andbust mining camps and more permanent settlements being built for lumber, railroads, and tourism. During the 1940s, the number of leases increased on national forest land for the development of summer homes. The Sierra Nevada experienced a second gold rush of new residents in the latter half of the twentieth century attracted by the region's amenities such as open space, air quality and views. Population grew by 65 percent in the 1970s and 39 percent in the 1980s. This urban-to-rural migration fueled land subdivision and home construction and a shift to a service-based economy, away from traditional resource-based industries.

The population of the Sierra Nevada grew by 72,000 from 2000 to 2010 to a total of 788,000 people. Most of that growth was concentrated in the central area of the region, where access to major transportation infrastructure exists, while the northern and eastern areas experienced no or negative population growth. Overall regional population growth has been very similar to that of California as a whole. However, the population of the region is less diverse and older than the rest of the state.

\section{Ecosystem Services}

The Food and Agriculture Organization of the United Nations defines ecosystem services as the benefits provided by ecosystems to humans. These services can be divided into four categories: supporting life through nutrient cycling, soil formation, and 
other processes; provisioning of food, water, and other resources; regulating the climate and purifying water; and providing cultural and spiritual heritage and recreation. The Sierra Nevada ecosystem produced about $\$ 2.2$ billion in commodities and services each year by 1996, with more than 60 percent of that coming from direct value in water and water-supported services. Other estimates include $\$ 131$ million in crops and livestock, $\$ 45$ million in grazing revenues, and over $\$ 1$ billion from recreation and tourism (Stewart 1996). The value of ecosystem services is affected by many things such as development, habitat loss, invasive species, increasing wildfire severity, human activities, and climate change. Several studies are currently being done to quantify how to enhance Sierra ecosystem services, assess market values to the services, map production and consumption, and identify ecosystem conservation opportunities.

\section{Water}

The Sierra Nevada bioregion receives around 30 percent of the state's annual precipitation in the form of rain or snow but provides almost 60 percent of the state's water needs through an extensive system of dams, reservoirs, and canals. Approximately 15 million acre-feet of water are stored as snowpack each winter, the largest water storage system in the state. Meadows and forests help filter water as it recharges groundwater systems and also help regulate the reliability of runoff during spring and

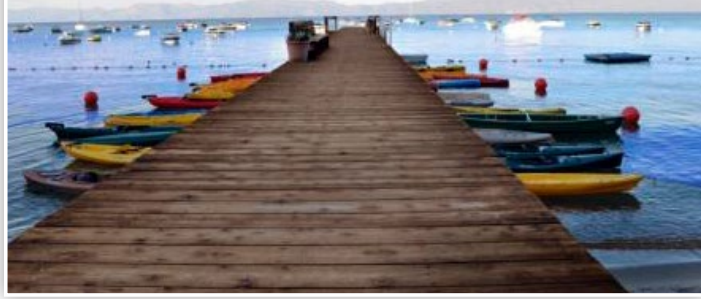
summer months. The amount of water stored each year is directly related to precipitation, climate, and biomass.

This plentiful water supply allowed the Sacramento-San Joaquin Valley to become one of the most productive agricultural areas in the United States. The Oroville Dam on the Feather River alone provides drinking

Kayaks on Lake Tahoe. Photo: ANR. water to more than 23 million Californians. To manage this resource, the State Water Project, which was initially conceived in 1919, includes 34 storage facilities, reservoirs, and lakes; 20 pumping plants; 4 pumping-generation plants; 5 hydroelectric power plants; and about 700 miles of open canals and pipelines. Large hydroelectric power facilities in the Sierra Nevada account for 73.5 percent of the state's hydroelectric capacity. The 9,300 megawatts of capacity had a retail value of $\$ 2.4$ billion in 2010 (DWR 2010).

\section{Timber}

The Sierra Nevada is comprised of about 10 million acres of productive forest land capable of producing timber sustainably. The production of timber from the Sierra Nevada peaked in the 1980s at about 1.8 billion board feet. Reductions in timber harvests from national forest lands began in the early 1990s as a result of restrictions initially instituted for protection of California spotted owl habitat. National forests currently grow vastly more wood fiber annually than is harvested.

\section{Biomass and Carbon Sequestration}

Sierra Nevada forests are estimated to support about 840 million tons of aboveground dry biomass, representing about 420 million tons of stored carbon. Nearly half of the total forest biomass occurs in mixed conifer forests, and about 62 percent of this is on public lands. Biomass is generally considered to be an indicator of the productivity of the ecosystem as well as of the decomposition rates and major disturbances that occur there. Current studies suggest that California mixed conifer forests store about 107 total tons of carbon per acre. Only half the stored carbon is found in the stems of trees; much is in the branches, and about 20 percent is contained in the soil.

Currently, much more biomass is stored in the Sierra than before fire suppression began early in the last century. This excess biomass has been used to produce renewable energy and reduce wildfire risk for over 30 years. Bark and limbs from timber harvesting and fuel reduction projects have been used to generate electricity at lumber mills or stand-alone biomass facilities located mostly in the Sierra foothills. Unfortunately, policy and market changes have reduced the viability of this industry, reducing the ability to recover costs from needed but expensive forest fuel reduction treatments. A recent effort is focusing on developing policies to enable construction of small-scale biomass facilities throughout the range. 


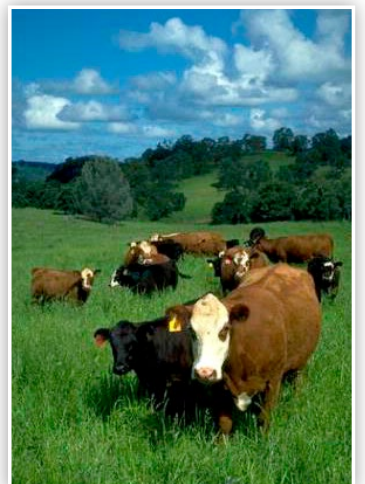

Cattle grazing at Sierra Foothills Research and Extension Center. Photo: ANR.

\section{Grazing and Farming}

Cattle ranching on private lands in the foothills of the Sierra makes up a large portion of the agriculture in the region, though wine grape vineyards are continuing to expand in the western foothills. However, cash farm income from the counties in the Sierra Nevada remains among the lowest in the state. Some cattle ranchers depend on public grazing permits to supply high-protein green forage during the summer dry season, but grazing on public lands is becoming less available. The effects of grazing on public land depend on factors such as timing, frequency, duration, and intensity. Grazing effects on the landscape range from the negative, such as defecation in streams, to the positive, such as reducing fire hazard. More research is needed as grazing effects on riparian systems and plant communities depend on location and the previously mentioned factors (Allen-Diaz 1999).

\section{Recreation}

Numerous recreational activities in the Sierra Nevada are occur yearround in eight national forests (Eldorado, Inyo, Plumas, Sequoia, Sierra, Stanislaus, Tahoe, and Lake Tahoe Basin Management Unit); three national parks (Sequoia, Kings Canyon, and Yosemite); two national monuments (Devil's Postpile and Sequoia); three Bureau of Land Management resource areas (Bishop, Folsom, and Eagle Lake); twelve Bureau of Reclamation facilities; many state parks; several campgrounds and reservoirs supported by utility companies; and countless private recreational facilities. The scenic lands and cultural/ historic resources of the Sierra not only provide enjoyment to local residents, they support a multi-billion-dollar tourism industry, which is the single most important economic activity in a number of Sierra counties (Sierra Nevada Conservancy 2011).

Recreation causes varying degrees of impact on the natural environment, from temporary to long-term at the local to regional scale. Negative impacts can occur from physical site disturbances such as material removal, disturbance and harvesting of flora and fauna, and water quality issues. Because of the numerous recreational opportunities and the sheer number of people involved, conflicts can also arise between the different types of users and their goals.

\section{Restoration Challenges}

Wildfire Risk/Excess Biomass

As vegetation continues to grow and stands increase in density due to fire suppression, overall biomass increases. Forests and woodlands where excess trees are growing have fewer soil and moisture resources available per individual tree, leaving trees less healthy and less able to withstand drought, insects, and disease. The effects of vegetation density can be devastating when a wildfire occurs. As a fire moves rapidly through dense stands of trees, it releases carbon, smoke and particulate matter into the atmosphere and exhibits extreme fire behavior, making it difficult to manage. This leads to unnaturally high-severity fires that are more likely to kill all the trees in the affected area, leaving none behind to generate seeds for the next generation.

Fuels reduction projects are one way of reducing fire severity and greenhouse gas emissions from wildfires by thinning biomass. When conifers are of sufficient size (about 10 inches in diameter), they have commercial value and can be sold to a sawmill to create lumber and offset the cost of treatments. Smaller-diameter trees and tops and limbs left over from fuels reduction projects are often disposed of by piling and burning. In some areas, fuel reduction is aided by the existence of biomass energy facilities that generate heat and power for local communities by using the slash piles and other biomass residue. Thinning of vegetation in oak woodland areas is also important, though there are fewer opportunities there to offset treatment costs.

The use of prescribed fire to reduce fuels, as well as "managed wildfire," in which natural fires

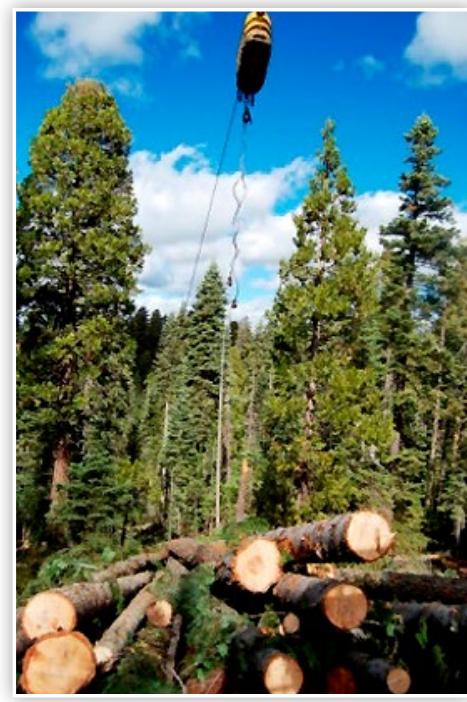

Cable logging, Tahoe National Forest. Photo: S. Kocher. 


\section{Destructive Wildfires Increasing} in the Sierra Nevada

The Rim Fire started in August 2013 when a hunter lost control of an illegal campfire and eventually burned over 250,000 acres in Tuolumne and Mariposa Counties. It was the largest wildfire in the history of the Sierra Nevada, and an unnaturally high proportion of areas were burned so severely that almost all the trees were killed. About 40 percent of the burned area, or 100,000 acres, on the Stanislaus National Forest, Yosemite National Park, and private land burned at high severity. This increase in high-severity burns continues a trend documented from the late twentieth century to larger patches of tree mortality.

Environmental impacts from increasing high-severity fire include a potential for increased soil erosion in areas denuded of litter cover, loss of high-density forest needed by old-growth-dependent species such as the California spotted owl and Pacific fisher, and vegetation type conversion to chaparral in areas where no living trees remain to provide seeds for the next forest.

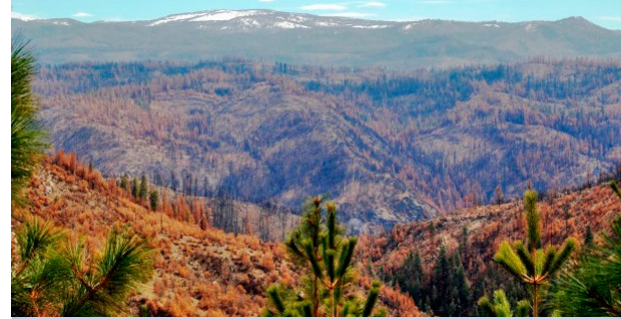

August 2013 Rim Fire area in March 2014. Photo: S. Kocher.

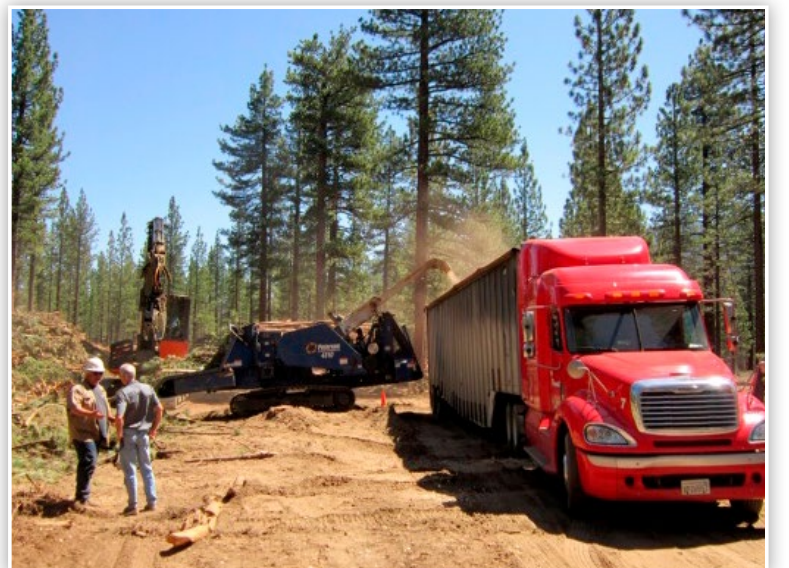

Left: Chip production for use at a biomass facility, Tahoe National Forest. Photo: B. Storey.

Right: Aspen grove. Photo: S. Kocher.

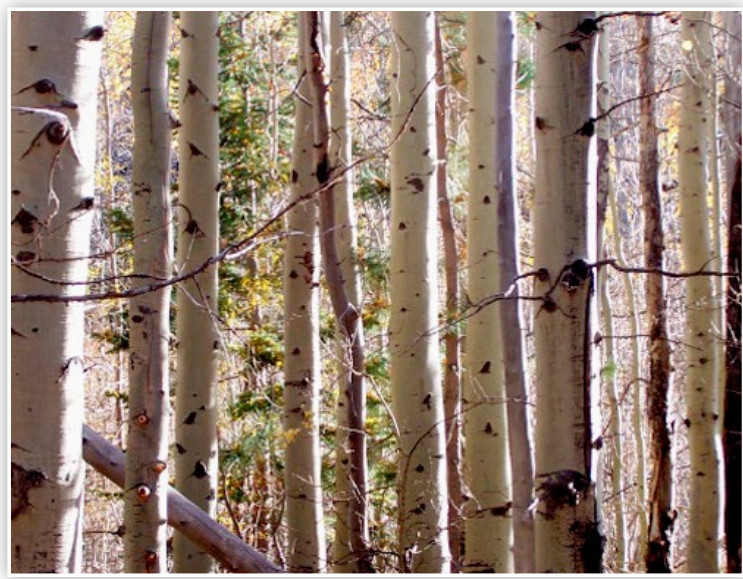

are allowed to burn as long as they burn within desired conditions, is also becoming more common. These methods have been shown to be effective at reducing biomass and wildfire risk. However, many issues prevent these techniques from being used routinely including, smoke generation and the need to protect life and property.

\section{Aspen Groves}

Aspens (Populus tremuloides) are native to the Sierra Nevada, where they thrive in the bright light and cool summer temperatures of mountain riparian communities. They have evolved with low- to moderate-intensity fire regimes that burn competing conifers that will otherwise overtop and shade them out. Fires also benefit aspen by reducing shrub competition and stimulating sucker growth. Groves are typically clonal colonies that grow from a single seedling and spread when roots come to the surface and begin to generate a sapling. Each tree lives 40 to 150 years above the ground, but the root system can be much older. Aspen groves are valued for providing a variety of ecological services, such as species and landscape diversity, aesthetics, wildlife habitat, forage for livestock and wildlife, and retaining more water than adjoining conifers. However, aspen stands have been on the decline in the Sierra due to fire suppression, pressure from encroaching conifers that shade them and compete for water, and, in some areas, overgrazing.

Aspen regeneration requires hormonal stimulation to initiate bud growth, sunlight and soil warmth, and protection from competing plants and grazing animals. Techniques to stimulate aspen growth include removal of existing decadent trees, removal of competing conifers and other vegetation, separation of roots from parent trees, and wildfire and prescribed burning at high intensity (USDA/USFS 2015). Physical barriers can be constructed to provide protection from browsing animals. However, these restoration practices also come with challenges. Soil compaction and stream and meadow damage can occur with harvesting practices, though this damage can largely be avoided by using best management practices (BMPs). Animal species that depend on canopy cover or nesting structures can be affected when the overstory is removed, although these changes are by nature temporary.

\section{Invasive Species}

An invasive species is any nonnative species that significantly arrive in new areas through natural migration, or by the activities of other species. In the Sierra Nevada, certain plant, animal, insect modifies or disrupts the ecosystems it colonizes. Such species may 
and fungal species are considered invasive. Some arrived with human activities, such as the tree-of-heaven (Ailanthus altissima) and black locust (Robinia psuedoacacia), which were introduced to California during the Gold Rush to be used as a fast-growing shade tree or as handles for tools. Both are now widespread throughout the Sierra and are particularly abundant in riparian and roadside areas. Others came as they expanded their natural range, such as the barred owl (Strix varia) that originated in south-central Mexico and north into the southern and eastern United States. The barred owl continued its western expansion and was first detected in California in the early 1980s. Some invasive species, such as white pine blister rust, were introduced accidently. Managing invasive species is a long-term process that includes eradication where possible, containment in certain conditions, and continuous surveillance in monitoring its effects. Education is also an important aspect in the control of invasive species. Visitors might have their boat inspected to help control the spread of hydrilla (Hydrilla verticillata) and Quagga mussels (Dreissena rostriformis bugensis) in high mountain lakes. Camp hosts remind people to "buy it where you burn it," referring to using local firewood to toast your marshmallows to help control the spread of invasive insects such as the emerald ash borer insect (Agrilus planipennis). Garden centers throughout the Sierra are discouraged from stocking plants such as Scotch broom (Cytisus scoparius), which are rapidly spreading and taking over native plant habitat.

\section{Climate Change}

The climate of the Sierra Nevada has been changing in the past half century. Temperatures are increasing, though whether precipitation will increase or decrease in the long run is not yet known. An additional temperature increase of just a few degrees is enough to turn snow into rain throughout the rain-snow transition zone. Depending on the model used, the spring Sierra Nevada snowpack could be reduced by as much as 70 to 90 percent by the end of the century. Snowpack reduction will be concentrated in the northern, lower-elevation end of the range. This has profound implications to water supply and hydropower generation, affecting farmers and urban consumers in California. The longer dry season is predicted to increase pine beetle activity among already-stressed trees, increase the length of the fire season, and double the area burned in wildfires by the end of the century. Winter recreation opportunities would be curtailed, affecting winter tourism and jobs in the ski industry and resort towns.

For Sierra plants and wildlife, climate change will affect the suitability of habitat. Plants that are at the warmest edge of their tolerance may migrate north or uphill in subsequent generations. Wildlife may already be making this adjustment. However, this ability is limited for species in the subalpine zone that have little territory uphill to expand toward. Of special concern is the whitebark pine, which could effectively be "pushed" off the mountain in the northern Sierra by moving its lower elevation limits above the tallest peaks. This stress is in addition to insect and disease threats to the pine. Prospects for maintaining subalpine species are better in the southern, higher end of the range.

\section{Explore!}

From the north to the south, the Sierra Nevada has a wide variety of places to explore and learn about what makes it so special.

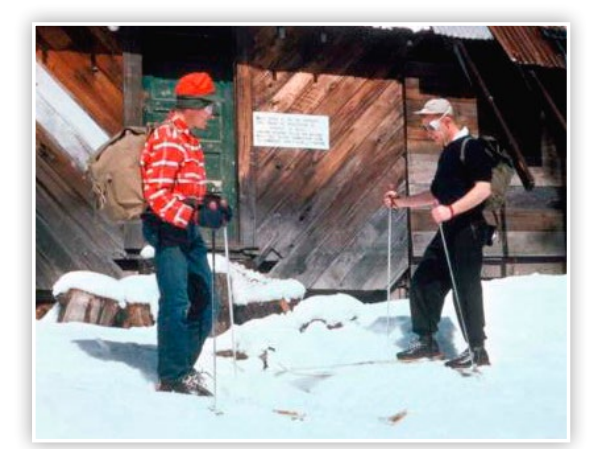

Cross-country skiing. Photo: ANR.

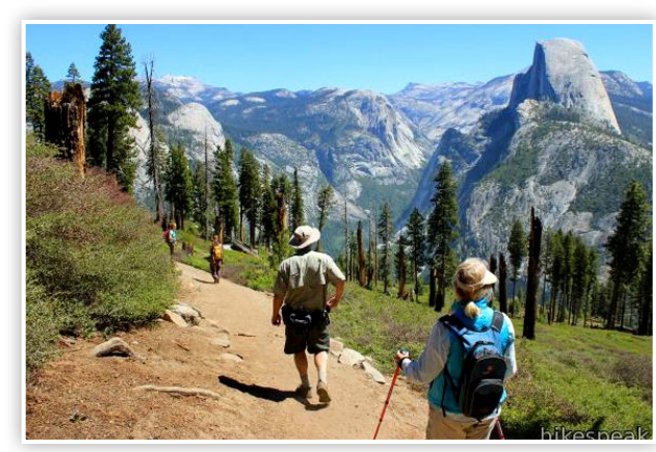

Hiking. Photo: S. Smigelski. 
Here are a few stops that will give you an excellent overview of the Sierra Nevada.

- The Sierra Nevada Conservancy, in conjunction with National Geographic, has produced a geotourism map that can help you plan a wonderful Sierra adventure (www.SierraNevadaGeotourism.org).

- Plumas County Museum, Quincy. Explore human interactions with the Sierra, including mining and logging exhibits, a late 1800s pioneer cabin, local Native American Mountain Maidu basketry, and Chinese immigrant contributions.

- Sierra Buttes and Lake Basin Recreation Area. Located north of Highway 49 along the Pacific Crest National Scenic Trail, this is one of the most scenic backcountry recreation areas in the Sierra. Enjoy fishing, swimming, biking, hiking, snowshoeing, and cross-country skiing.

- Marshall Gold Discovery State Historic Park, Coloma. Visit the site where James Marshall's discovery of gold began the California Gold Rush.

- California Cavern State Historic Landmark, San Andreas. With a guide, explore mapped subterranean passages, or for the more adventurous, the undeveloped parts of this cave complex.

- Trail of 100 Giants, Johnsondale. This trail takes you through a giant Sequoia grove.

- Tomo-Kahni State Historic Park, Monolith. This park, open by tour only, is the ancestral home of the Kawaiisu people. Guided hikes lead you past cave paintings and grinding holes.

\section{Bibliography}

Allen-Diaz, B., R. Barrett, W. Frost, L. Huntsinger, and K. Tate. 1999. Sierra Nevada ecosystems in the presence of livestock. A report to the USDA Forest Service Pacific Southwest Station and Region. Albany, CA: USDA Forest Service.

Beedy, E. C., and E. R. Pandolfino. 2013. Birds of the Sierra Nevada: Their natural history, status and distribution. Berkeley: University of California Press.

Carle, D. 2004. California natural history guide \#76: Introduction to WATER in California. Berkeley: University of California Press.
CDFG (California Department of Fish and Game). 2015. Fisher Translocation Project description. CDFG website, r1.dfg.ca.gov/portal/ FisherTranslocationProject/ProjectDescription/tabid/841/Default.aspx.

Conservation International. 2005. CI facts: Biodiversity hotspot. Conservation International website, www.cnrs.fr/inee/recherche/ fichiers/Biodiversite_hotspots.pdf.

DWR (California Department of Water Resources). 2010. California State Water Project overview. DWR website, www.water.ca.gov/swp/.

Erman, D. C. 1996. Status of the Sierra Nevada: The Sierra Nevada Ecosystem Project. Washington, DC: US Department of the Interior and US Geological Survey.

Fire Adapted Communities. 2015. Fire Adapted Communities website, www.fireadapted.org.

Gruell, G.E. 2001. Fire in Sierra Nevada forests: A photographic interpretation of ecological change since 1849. Missoula, MT: Mountain Press.

James, L. Allan, J. Harbor, D. Dahms, and D. Elmore. 2002. Late Pleistocene glaciations in the northwestern Sierra Nevada, California. Quaternary Research 57:409-419.

Knapp, E. E. 2015. Long-term dead wood changes in a Sierra Nevada mixed conifer forest: Habitat and fire hazard implications. Forest Ecology and Management 339:87-95.

Kocher, S. 2012. System indicators: Forest health and carbon storage. Auburn, CA: Sierra Nevada Conservancy Final Report.

Kuchera, D., and J. Hester. 2009. Mining techniques of the Sierra Nevada and Gold Country. Snowy Range Reflections 2:1. Sierra College website, www.sierracollege.edu/ejournals/jsnhb/v2n1/ miningtechniques.html.

Laws, J. M. 2007. The Laws field guide to the Sierra Nevada. Berkeley: California Academy of Sciences/Heyday Books, 2007.

McIntyre P. J., J. H. Thorne, C. R. Dolanc, et al. 2015. Twentiethcentury shifts in forest structure in California: Denser forests, smaller trees, and increased dominance of oaks. Proceedings of the National Academy of Sciences 12:1458-1463. 
National Park Service. 2015. Yosemite National Park Mammals. NPS website, www.nps.gov/yose/naturescience/mammals.htm.

PG\&E (Pacific Gas and Electric Company). 2015. Hydroelectric system. PG\&E website, www.pge.com/en/safety/systemworks/ hydro/index.page.

Raphael, M.G., M. L. Morrison, and M. P. Yoder-William. 1987. Breeding bird populations during twenty-five years of postfire succession in the Sierra Nevada. The Condor 89(3): 614-626.

Sierra Club. 2015. John Muir exhibit: A brief biography. Sierra Club website, vault.sierraclub.org/john_muir_exhibit/life/muir_ biography.aspx.

Sierra Nevada Conservancy. 2011. Strategic plan. SNC website, www.sierranevada.ca.gov/about-us/docs/StratPlan2011.pdf.

Stewart, W. C. 1996. Economic assessment of the ecosystem. In Sierra Nevada Ecosystem Project Final Report to Congress. Vol. 3. Assessments and scientific basis for management options. Davis: University of California Centers for Water and Wildland Resources.

Storer, T. L., R. L. Usinger, and D. Lukas. 2004. Sierra Nevada natural history. Berkeley: University of California Press.

Tahoe Environmental Research Center (UC Davis). 2014. Tahoe: State of the Lake Report, 2014. terc.ucdavis.edu/stateofthelake/ sotl-reports/2014/sotl_2014_complete.pdf

Tunage, William. 2015. Ansel Adams Biography. The Ansel Adams Gallery. www.anseladams.com/ansel-adams-information/anseladams-biography/

UC (University of California). 2015. Natural Reserve System, University of California. UC Office of the President website, nrs.ucop.edu.

USDA/USFS (U.S. Department of Agriculture/U.S. Forest Service). 2015. Aspen ecology. USFS website, www.fs.fed.us/wildflowers/ beauty/aspen/ecology.shtml.

Van Wagtendonk, J. W., and J. A. Fites-Kaufman. 2006. Sierra Nevada bioregion. In N. G. Sughiara, ed., Fire in California's ecosystems. Berkeley: University of California Press.
The California Naturalist Program, calnat.ucanr.edu/, is a Statewide Program of the University of California Division of Agriculture and Natural Resources.

To order or obtain ANR publications and other products, visit the ANR Communication Services online catalog at http://anrcatalog.ucanr.edu/ or phone 1-800-994-8849. You can also place orders by mail or FAX, or request a printed catalog of our products from

University of California

Agriculture and Natural Resources

Communication Services

1301 S. 46th Street, Building 478 - MC 3580

Richmond, CA 94804-4600

Telephone 1-800-994-8849, 510-665-2195

FAX 510-665-3427

E-mail: anrcatalog@ucanr.edu

@2015 The Regents of the University of California. This work is licensed under the Creative Commons Attribution-NonCommercial-NoDerivatives 4.0 International License. To view a copy of this license, visit http://creativecommons. org/licenses/by-nc-nd/4.0/ or send a letter to Creative Commons, PO Box 1866, Mountain View, CA 94042, USA.

Publication 8535

ISBN-13: 978-1-60107-931-2

The University of California, Division of Agriculture and Natural Resources (UC ANR), in accordance with applicable Federal and State laws and University policy, prohibits discrimination against or harassment of on the basis of race, color, national origin, religion, sex, gender, gender expression, gender identity, pregnancy (which includes pregnancy, childbirth, and medical conditions related to pregnancy or childbirth), physical or mental disability, medical condition (cancer-related or genetic characteristics), genetic information (including family medical history), ancestry, marital status, age, sexual orientation, citizenship, status as a protected veteran or service in the uniformed services (as defined by the Uniformed Services Employment and Reemployment Rights Act of 1994 [USERRA]), as well as state military and naval service. The University also prohibits sexual harassment and sexual violence. These policies cover employment, access, and treatment in University programs and activities. The policy can be found at http://ucanr.edu/sites/anrstaff/files/215468.pdf.

An electronic copy of this publication can be found at the ANR Communication Services catalog website, http://anrcatalog.ucanr.edu/.

UC This publication has been anonymously peer reviewed for tech-

PEER REVED nical accuracy by University of California scientists and other qualified professionals. This review process was managed by ANR Associate Editor for Natural, Marine, and Freshwater Resources William C. Stewart.

web-10/15-SB/BG 


\section{Contents}

Ansel Adams Spreads Images of the Sierra in Popular Consciousness

Introduction

John Muir Founds Preservation Movement in Sierra Nevada

Figure 1. Sierra Bioregion.

Living in the Wildland-Urban Interface

\section{Geology and Climate}

Frozen Lake Tenaya. Photo: R. Miller-Cripps.

\section{Watersheds}

\section{Forest and Woodland Types}

Figure 2. Watersheds of the Sierra Nevada bioregion. Source: The Sierra Nevada Conservancy.

Oak woodlands at the University of California Sierra

Foothill Research and Extension Center. Photo: ANR.

Mixed conifer zone on the Tahoe National Forest. Photo: S. Stephens.

\section{Oak Woodland}

Montane Hardwood/Conifer

Mixed Conifer

Giant Sequoias. Photo: S. Kocher.

True Fir Forest

Subalpine Forest

Alpine Zone

Eastside Pine

Biodiversity

Scientists Work to Reveal the Secrets of the Pacific

Fisher

Animal Communities

Pacific fisher. Photo: SNAMP remote camera.

Lahontan cutthroat trout.

Photo: K. Ingram
Fish

Birds

California spotted owl.

Pacific fisher. Photo: SNAMP

camera.

Photo: S. Whitmore

remote

Black bear cub. Photo: ANR.

Mammals

Insects

Sensitive Species

\section{Disturbance and Adaptation}

Figure 3. Mean reference fire return interval. Source: Map by Steve Beckwitt, Sierra Nevada Conservancy.

Hydraulic Mining Battle Begins Era of Environmental Regulation

\section{Human History}

Public and Private Land Ownership

Mining

Hetch Hetchy Fuels Controversy over Dams and Water Supply

Transportation

Timber Harvest

Grazing

Water Development

Recreational Development

Lake Tahoe Region Becomes Entry to the Sierra for Millions Annually

Residential Development

\section{Ecosystem Services}

Emerald Bay, Lake Tahoe. Photo: Christine B.

Kayaks on Lake Tahoe. Photo: ANR.

Water

Timber

Biomass and Carbon Sequestration
Cattle grazing at Sierra Foothills Research and Extension Center. Photo: ANR.

Grazing and Farming

Recreation

\section{Restoration Challenges}

Wildfire Risk/Excess Biomass

Cable logging, Tahoe National Forest. Photo: S. Kocher.

Destructive Wildfires Increasing

in the Sierra

Nevada

August 2013 Rim Fire area in March 2014. Photo: S. Kocher.

Aspen Groves

Invasive Species

Left: Chip production for use at a biomass facility, Tahoe National Forest. Photo: B. Storey.

Right: Aspen grove. Photo: S. Kocher.

\section{Climate Change}

\section{Explore!}

Cross-country skiing. Photo: ANR.

Hiking. Photo: S. Smigelski.

Bibliography 